GRASAS Y ACEITES 72 (3)

July-September 2021, e416

ISSN-L: 0017-3495

https://doi.org/10.3989/gya.0450201

\title{
Batoko plum (Flacourtia inermis) peel extract attenuates deteriorative oxidation of selected edible oils
}

\author{
(1)N.E. Wedamulla ${ }^{\varpi}$ and $\odot$ W.A.J.P. Wijesinghe \\ Department of Export Agriculture, Faculty of Animal Science and Export Agriculture, Uva Wellassa University, Badulla, Sri Lanka. \\ ${ }^{\circledR}$ Corresponding author: nishala.erandi@yahoo.com
}

Submitted: 28 April 2020; Accepted: 04 June 2020; Published online: 14 September 2021

SUMMARY: The oxidation of oils has an adverse effect on the organoleptic properties and shelf-life of stored oils. Flacourtia inermis is one of the underutilized fruits grown in Sri Lanka with promising antioxidant properties. F. inermis peel extract (FIPE) was used to retard rancidity in edible oils. The efficacy of added FIPE (500, 1000, $2000 \mathrm{ppm})$ on sunflower oil (SO) and virgin coconut oil (VCO) was monitored at 3-day intervals at $65 \pm 5{ }^{\circ} \mathrm{C}$ against a positive control ( $\alpha$-tocopherol at $500 \mathrm{ppm}$ level) using Free Fatty Acid (FFA) and Peroxide Value (PV). Oils without FIPE were used as the control. Antioxidant efficacy $\left(\mathrm{IC}_{50}\right)$ and Total Phenol Content (TPC) of FIPE were determined by DPPH assay and the Folin-Ciocalteu method. Fourier transform infrared spectroscopy was used to monitor the oxidative stability. The $\mathrm{IC}_{50}$ value and TPC of FIPE were $227.14 \pm 4.12 \mu \mathrm{g} \cdot \mathrm{mL}^{-1}$ and $4.87 \pm 0.01 \mathrm{mg} \mathrm{GAE} / \mathrm{g}$ extract, respectively. After 21 days, VCO (control) sample exhibited significantly $(\mathrm{p}<0.05)$ higher FFA and PV than the treatments. FIPE exhibited comparable results with $\alpha$-tocopherol. Conclusively, FIPE had strong antioxidant properties and thus, could be used as an alternative to $\alpha$-tocopherol to improve the oxidative stability of virgin coconut oil and sunflower oil. However, only minor differences in the FTIR spectra were detected in treated and untreated virgin coconut and sunflower oil samples after 21 days storage at $65 \pm 5^{\circ} \mathrm{C}$.

KEYWORDS: Antioxidant efficacy; Coconut oil; Flacourtia inermis; Oxidative stability; Sunflower oil

RESUMEN: Extracto de piel de ciruela Batoko (Flacourtia inermis) para atenuar el deterioro oxidativo de aceites comestibles seleccionados. La oxidación afecta negativamente a las propiedades organolépticas y a la vida útil de los aceites almacenados. Flacourtia inermis es una de las frutas infrautilizadas cultivadas en Sri Lanka con prometedoras propiedades antioxidantes. En este contexto, se utilizó el extracto de cáscara de $F$. inermis (FIPE) para retardar la rancidez de los aceites comestibles. La eficacia de FIPE añadido (500, $1000,2000 \mathrm{ppm}$ ) a aceite de girasol (SO) y a aceite de coco virgen (VCO) se controló a intervalos de 3 días a $65 \pm 5{ }^{\circ} \mathrm{C}$ frente a un control positivo ( $\alpha$-tocoferol a nivel de $500 \mathrm{ppm}$ ) y utilizando las determinaciones de acidez libre (FFA) e índice de peróxido (PV). Se usaron aceites sin FIPE como control. La eficacia antioxidante (IC50) y el contenido total de fenoles (TPC) de FIPE se midieron mediante el ensayo DPPH y el método de Folin-Ciocalteu. La espectroscopía infrarroja por transformada de Fourier se utilizó para controlar la estabilidad oxidativa. El valor de CI50 y el TPC de FIPE fueron $227,14 \pm 4,12 \mu \mathrm{g} \cdot \mathrm{mL}^{-1}$ y $4,87 \pm 0,01 \mathrm{mg}$ de extracto de GAE / g, respectivamente. Tras 21 días, la muestra de VCO (control) mostró valores significativamente más altos $(\mathrm{p}<0.05)$ de FFA y PV que los tratamientos. FIPE exhibió resultados comparables con $\alpha$-tocoferol. En conclusión, FIPE tiene fuertes propiedades antioxidantes, por lo que podría usarse como una alternativa al $\alpha$-tocoferol para mejorar la estabilidad oxidativa de aceites de coco virgen y de girasol. Sin embargo, solo se mostraron diferencias menores en los espectros FTIR de las muestras de aceite de coco y girasol tratadas y no tratadas tras 21 días de almacenamiento a $65 \pm 5{ }^{\circ} \mathrm{C}$.

PALABRAS CLAVE: Aceite de coco; Aceite de girasol; Eficacia antioxidante; Estabilidad oxidativa; Flacourtia inermis

Citation/Cómo citar este artículo: Wedamulla NE, Wijesinghe WAJP. 2021. Batoko plum (Flacourtia inermis) peel extract attenuates deteriorative oxidation of selected edible oils. Grasas Aceites 72 (3), e416. https://doi.org/10.3989/gya.0450201

Copyright: (C2021 CSIC. This is an open-access article distributed under the terms of the Creative Commons Attribution 4.0 International (CC BY 4.0) License. 


\section{INTRODUCTION}

Fats and oils play a vital role in the human diet owing to their nutritional value. Soybean, palm, rapeseed and sunflower oil are identified as the most widely consumed edible oils. Among them, sunflower oil is the second most widely used oil in Europe (Arshad and Amjad, 2012) and contains high amounts of vitamin E, essential fatty acids and a low level of saturated fat (Madhavi et al., 2010). Recently, virgin coconut oil (VCO) has drawn considerable attention from the scientific community as VCO contains a significant amount of mediumchain fatty acids viz. capric, caproic and caprylic acids which are proven to have antimicrobial and antiviral properties (Villarino et al., 2007).

Edible oils are subjected to oxidation during processing and storage via different chemical mechanisms viz. autoxidation and photosensitized oxidation (Choe and Min, 2006) which modifies organoleptic properties while affecting the shelflife (Lercker and Rodriguez-Estrada, 2002) with a strong impact on the final quality of foods (Capuano et al., 2010). This lipid oxidation also contributes to decreasing the nutritional quality in addition to the production of rancid odors, unpleasant flavors and discoloration (Abdelazim et al., 2013). Thus, the oxidative stability of edible oils is one of the major concerns in the food industry; and oxidative stability is simply defined as "resistance to oxidation during processing and storage" (Guillén and Cabo, 2002).

There is a growing tendency toward using synthetic antioxidants such as butylated hydroxyanisole (BHA), butylated hydroxytoluene (BHT) and tert-butyl hydroquinone (TBHQ) to improve the oxidative stability of edible oils in order to overcome the adverse effects associated with lipid oxidation. However, an influx of literature has revealed that these compounds are associated with many health hazards, including cancer and carcinogenesis (Abdelazim et al., 2013). In light of this information, a surge of studies has been directed towards the addition of natural antioxidants in order to retard the rancidity of edible oils (Latha, 2009).

Natural antioxidants have drawn considerable attention owing to their potential role in preventing chronic diseases (Falowo et al., 2014). These antioxidants also inhibit or slow down the formation of free radicals and retard lipid oxidation by inhibiting the initiation or propagation of oxidative chain reactions (Latha, 2009). A number of local fruits grown in Sri Lanka has been identified as an excellent source of natural antioxidants. Moreover, many underutilized fruits exhibit greater amounts of promising antioxidant properties than commonly consumed fruits (Piyathunga et al., 2016).

The fruit from Flacourtia inermis (Sri Lankan name: Lovi) of the family Flacourtiaceae is one of the underutilized fruits grown in Sri Lanka with promising antioxidant properties (Jayasinghe et al., 2012; Alakolanga et al., 2014). The fruit is round, cherry-sized, and dark red when ripe with fruit juice which has a deep red color (Alakolanga et al., 2015). Though many studies have proven the antioxidant activity of $F$. inermis fruit, the studies directed to assess the efficacy of $F$. inermis as a natural antioxidant are still scarce. Thus, the present study aims to utilize FIPE to retard the rancidity of selected edible oils as the peels of many fruits get wasted during processing regardless of their promising bioactive properties.

\section{MATERIALS AND METHODS}

\subsection{Materials}

Sunflower oil and virgin coconut oil were obtained from a local market in Badulla, Sri Lanka. $F$. inermis (Lovi) fruits were collected from the Western province of Sri Lanka. All of the reagents and solvents used were of analytical reagent grade.

\subsection{Extraction of natural antioxidants from the peel of $F$. inermis fruits}

Freeze-dried fruit peel was ground to a fine powder using a laboratory grinder. Dried, powdered peel was sieved (mesh size; $1 \mathrm{~mm}$ ) and stored at -18 ${ }^{\circ} \mathrm{C}$ temperature until extraction. Freeze dried peel powder $(20 \mathrm{~g})$ was dissolved in $200 \mathrm{~mL}$ of $70 \%$ aqueous ethanol and extracted using an ultrasonic cleaner (model UC -10 A, $40 \mathrm{kHz}$, Heater $50 \mathrm{w}$, Tank $2 \mathrm{~L}$, Tank size L $180 * \mathrm{~W} 165^{*} \mathrm{H} 180 \mathrm{~cm}$, China) at $40 \pm 5{ }^{\circ} \mathrm{C}$ for 30 minutes. The extraction procedure was repeated twice. The combined filtrate was concentrated in vacuo at $40 \pm 5^{\circ} \mathrm{C}$. Concentrated crude extract was stored at $-18^{\circ} \mathrm{C}$ until analysis.

\subsection{Determination of total phenol content (TPC)}

Total phenol content was determined according to the method of ISO 14502-1 with slight modifications. First, crude extract was dissolved in $70 \%$ methanol to obtain a $60 \mathrm{mg} \cdot \mathrm{L}^{-1}$ solution. Ten- 
fold diluted Folin-Ciocalteu reagent $(1.0 \mathrm{~mL})$ was added to $200 \mu \mathrm{L}$ plant extract and kept for $8 \mathrm{~min}$. Then $800 \mu \mathrm{L}$ of $7.5 \%$ (w/v) $\mathrm{Na}_{2} \mathrm{CO}_{3}$ (aq) were added and kept for $1 \mathrm{~h}$. The absorbance was measured at a wavelength of $765 \mathrm{~nm}$ (UV /Visible SP-UV 50 VDB spectrophotometer). Gallic acid was used as a standard and a calibration curve was plotted using the absorbance values for gallic acid solution series. The phenolic content of plant extracts was calculated using the calibration curve and expressed as $\mathrm{mg}$ of gallic acid equivalents (GAE)/ g extract.

\subsection{Determination of antioxidant activity}

The crude extracts (150-325 ppm) were tested using the 2,2-diphenyl-1-picrylhydrazyl (DPPH) assay (Ali et al., 2018). Each solution $(50 \mu \mathrm{L})$ was mixed with $50 \mu \mathrm{L}$ of $4 \times 10^{-4} \mathrm{M}$ methanolic DPPH Solution and kept in the dark at room temperature for $20 \mathrm{~min}$. The absorbance was measured at $517 \mathrm{~nm}$ using a microplate spectrophtometer (Multiskan Go, Version100.40, Thermo Fisher Scientific) against a reaction blank (50 $\mu \mathrm{L}$ of Methanol and $50 \mu \mathrm{L}$ of the crude extract). A mixture of $50 \mu \mathrm{L}$ of $4 \times 10^{-4} \mathrm{M}$ DPPH solution and 50 $\mu \mathrm{L}$ of methanol were used as a reaction control. Percent inhibition was calculated for each concentration and $\mathrm{IC}_{50}$ was calculated for crude extract. The following equation was used to calculate percent inhibition:

Present Inhibition $=\frac{\mathrm{Ac}-\mathrm{As}}{\mathrm{Ac}} \times 100$

$\mathrm{A}_{\mathrm{c}}$ : Absorbance of reaction control

$\mathrm{A}_{\mathrm{s}}$ : Absorbance of the test sample

\subsection{Sample preparation for storage of oils}

Oil samples with crude extract were prepared at three different concentrations viz 500 ppm, 1000 ppm and $2000 \mathrm{ppm}$ along with control (no added peel extract) and $\alpha$-tocopherol (500 ppm) was used as positive control. First, oil sample was pre heated in a water bath at $50{ }^{\circ} \mathrm{C}$ for 3 hours. The crude extract of fruit peel was dissolved in a small amount of absolute ethanol $(150 \mu \mathrm{L})$ to facilitate a uniform dispersion of extract in the oil. Oil samples with different concentrations of extracts were kept in an ultrasonic water bath at $60^{\circ} \mathrm{C}$ for $30 \mathrm{~min}$ to obtain a homogenous dispersed sample. A storage study of the oils was conducted as per the method described by Besbes et al., 2004 with slight modifications. Treated oils were completely filled into glass bottles (volume $25 \mathrm{~mL}$ ) wrapped with aluminum foil, sealed properly and stored in an oven at $65 \pm 5$ ${ }^{\circ} \mathrm{C}$ for 21 days. Oil samples were drawn for analysis at intervals of three days.

\subsection{Determination of peroxide value (PV)}

Peroxide values for the oil samples drawn at 3-day intervals were determined according to the standard procedures described as AOAC 965.33 (2016). Five grams of oil sample were dissolved in $30 \mathrm{~mL}$ of acetic acid: chloroform solution (3:2). Then, $0.5 \mathrm{~mL}$ of saturated KI solution were added and left to stand with occasional shaking for one minute and placed in the dark for $5 \mathrm{~min}$. Then, $30 \mathrm{~mL}$ of distilled water were added and the mixture was titrated slowly with $0.01 \mathrm{M}$ sodium thiosulfate. A blank was made according to same procedure without the addition of oil. The peroxide value (meq $\mathrm{O}_{2} \cdot \mathrm{kg}^{-1}$ of oil) of all samples was calculated according to the following equation:

Peroxide value $(\mathrm{mEq} / \mathrm{kg})=\frac{\mathrm{S} \times \mathrm{M} \times 1000}{\text { Sample weight }(\mathrm{g})}$

Where,

$\mathrm{S}$ is the volume of $\mathrm{Na}_{2} \mathrm{~S}_{2} \mathrm{O}_{3}$ used (blank corrected) $\mathrm{M}$ is the molarity of $\mathrm{Na}_{2} \mathrm{~S}_{2} \mathrm{O}_{3}$

\subsection{Determination of free fatty acid (FFA) content}

The free fatty acid contents of the oil samples drawn at 3-day intervals were determined according to the procedure described as AOAC 940.28 (2016). An accurately weighed oil sample was dissolved in $20 \mathrm{~mL}$ of previously neutralized absolute ethanol. The mixture was titrated with $0.05 \mathrm{M}$ sodium hydroxide with the addition of phenolphthalein as indicator with vigorous shaking until a permanent faint pink color appeared and persisted for more than $1 \mathrm{~min}$. The percentage of free fatty acids of each oil sample was calculated as oleic acid using the following equation:

$\%$ FFA (oleic acid $)=\frac{\mathrm{V} \times \mathrm{C} \times 282.46 \times 100}{\mathrm{M}}$

Where,

$\mathrm{V}$ is the volume of sodium hydroxide react in titration $(\mathrm{mL})$

$\mathrm{C}$ is the concentration of sodium hydroxide (M)

$\mathrm{M}$ is the mass of oil sample (g) 


\subsection{FTIR (Fourier transform infrared) analysis}

The absorption spectra of oil samples before and after 21 days of storage were measured on a FTIR spectrometer (Bruker, Alpha-T, German) using Deuterated Triglycine Sulphate (DTGS) as detector. They were interfaced to a computer operating under Windows-based, and connected to OPUS (Version 7.5) software. The samples were placed in contact with attenuated total reflectance (ATR) element (platinum) at controlled ambient temperature. FTIR spectra were collected in the frequency of 4000-500 $\mathrm{cm}^{-1}$ by co-adding 64 scans and at resolution of 4 $\mathrm{cm}^{-1}$. All spectra were rationed against a background of air spectrum.

\subsection{Statistical analysis}

Mean values of all data were obtained from triplicate determinations. Values were expressed are mean \pm SD. Data were subjected to analysis of variance (ANOVA) according to the GLM (general linear model). Data processing was done by the Minitab 16.1 version of the computer software package.

\section{RESULTS AND DISCUSSION}

\subsection{Antioxidant properties of $F$. inermis fruit peel extract}

The antioxidant efficacy of plant extracts can be tested using a wide variety of methods. In the present study, the free radical scavenging capacity of FIPE was evaluated by DPPH assay and expressed as $\mathrm{IC}_{50}$. Results of the present study revealed that the antioxidant activity of FIPE $\left(227.14 \pm 4.12 \mu \mathrm{g} \cdot \mathrm{mL}^{-1}\right)$ was significantly $(\mathrm{p}<0.05)$ lower than that of $\alpha$-tocopherol $\left(29.80 \pm 3.22 \mu \mathrm{g} \cdot \mathrm{mL}^{-1}\right)$. Alakolanga et al., (2015) observed comparatively high antioxidant activity $(66.2 \mathrm{ppm})$ in the ethyl acetate extract of $F$. inermis whole fruit. However, the methanolic extract of the reported study exhibited comparatively low antioxidant activity (212.95 ppm). The disparity of the results may be due to the difference in the extraction technique employed and the fruit material used in the two studies.

In the present study sonication was used as the extraction technique to extract natural antioxidants from the peel of lovi fruit as it is reported to enhance the extraction of bioactive compounds from plants and their products (Annegowda et al., 2010). The present study used 30 min sonication time for the extraction as prolonged sonication led to the decomposition of the bioactive constituents, and most of the active constituents inside the cells are released into the solvent during the first few minutes (Annegowda et al., 2010).

\subsection{Total phenol content of $\boldsymbol{F}$. inermis fruit peel extract}

The total phenol content of FIPE was determine using the Folin-Ciocalteau colorimetric method. The total phenolic content of a sample was calculated based on the calibration curve prepared using gallic acid as standard. The total phenol content of FIPE was $4.87 \pm 0.01 \mathrm{mg}$ GAE per $g$ extract. However, the study carried out by Alakolanga and others (2015) reported the polyphenol content of lovi fruit as 1.28 $\mathrm{g}$ gallic acid equivalents per $100 \mathrm{~g}$ of fresh fruit.

The extraction of phenolic compounds from plant materials is influenced by several factors: chemical nature of the plant materials, method of extraction, particle size of the sample (plant material), storage time and conditions, and the presence of interfering substances. The solubility of phenolic compounds is governed by the type of solvent (polarity of the solvent) used, the degree of polymerization of phenolics, the interaction of phenolics with other food constituents and the formation of insoluble complexes (Naczk and Shahidi, 2004). Thus, considering all these factors and the literature (Liew et al., 2018), the present study used $70 \%$ ethanol as the solvent for extraction.

\subsection{Variation in peroxide value $(\mathrm{PV})$ during storage of oils}

Peroxide value measures the formation of peroxide in the early stages of lipid oxidation. The present study measured the variation in peroxide value to determine the effect of FIPE addition on the oxidative stability of VCO and SO during storage at $65 \pm 5^{\circ} \mathrm{C}$. The peroxide values for the VCO samples treated with FIPE are shown in Figure 1 along with the control and positive control $\alpha$-tocopherol. The PV of all the oil samples increased during storage and thereby indicate the progression of lipid oxidation as PV is a good indicator of the extent of primary oxidative products formed in oils. Several studies have proven that the PV of VCO increased during storage at $63{ }^{\circ} \mathrm{C}$ (Rohman et al., 2011). However, the initial PV of the reported study was lower $\left(0.42 \pm 0.009\right.$ meq $\mathrm{O}_{2} \cdot \mathrm{kg}^{-1}$ oil $)$ than 

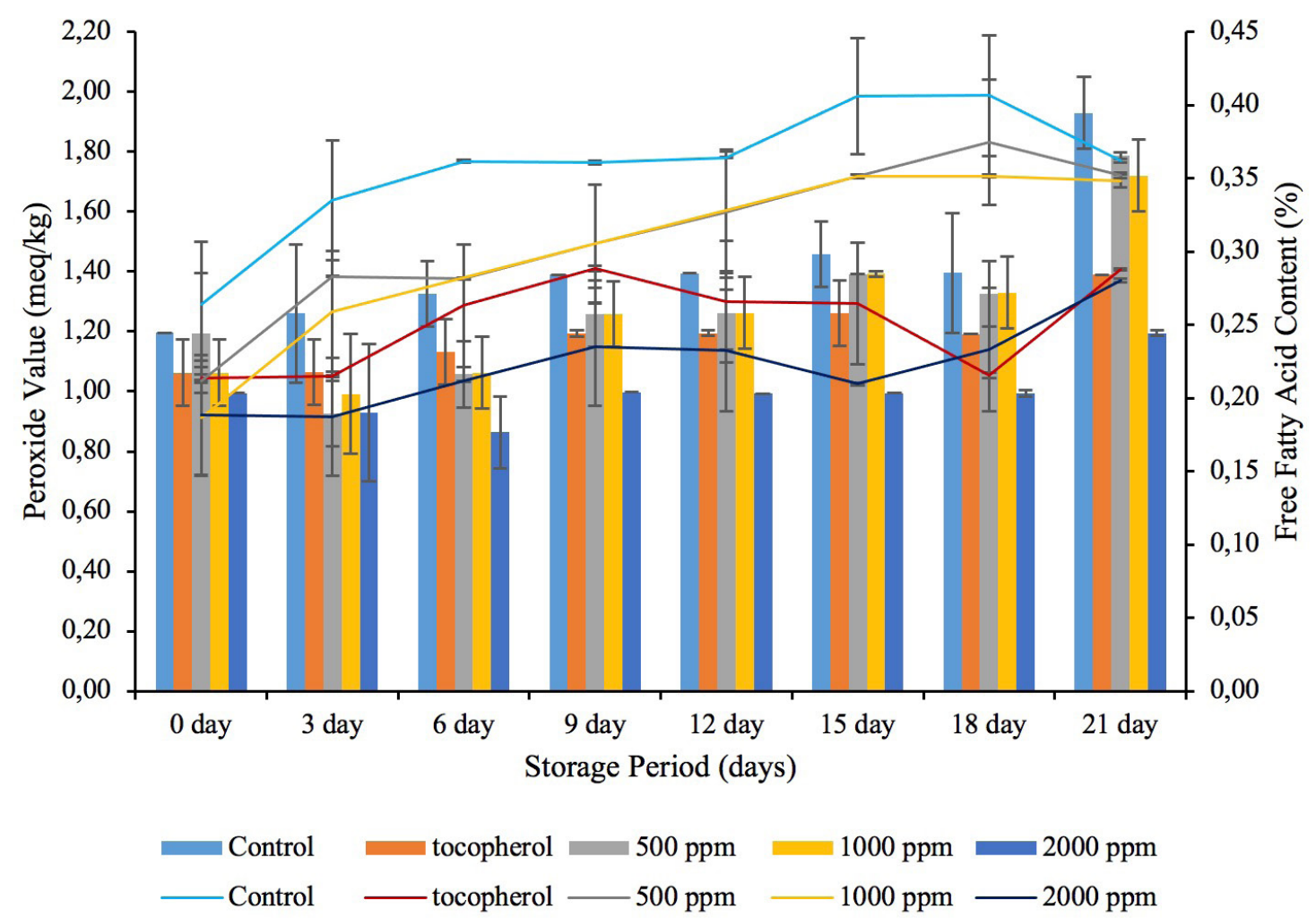

FIgURE 1. Variations in Peroxide Value and Free Fatty Acid Content in Virgin Coconut oil with added FIPE. Values are presented as mean \pm SD of three determinations.

that of the present study $\left(1.20 \pm 0.00\right.$ meq $\mathrm{O}_{2} \cdot \mathrm{kg}^{-1}$ oil $)$. The peroxide values of treated samples and control samples showed no significant difference $(p>0.05)$ up to the third day of storage. From day 6 onwards the PV of the control and treated samples showed significant difference $(\mathrm{p}<0.05)$; the PV value of the control sample was significantly $(p<0.05)$ higher than the $2000 \mathrm{ppm}$ level of the extract-added VCO sample from day 6 onward. However, there was no significant difference between the control and $500 \mathrm{ppm}$ and 1000 ppm levels of FIPE-added VCO samples after day 6 or day 18 . The highest peroxide value $(1.93 \pm 0.12 \mathrm{meq}$ $\mathrm{O}_{2} \cdot \mathrm{kg}^{-1}$ oil) was observed for the control sample after 21 days storage.

Meanwhile, the lowest peroxide value $(1.19 \pm$ $0.01 \mathrm{meq} \mathrm{O}_{2} \cdot \mathrm{kg}^{-1}$ oil) was reported for the VCO sample with 2000 ppm level of extract after 21 days of storage (Figure 1). There was no significant difference between the oil treated with $\alpha$ - tocopherol $\left(1.39 \pm 0.00\right.$ meq $\mathrm{O}_{2} \cdot \mathrm{kg}^{-1}$ oil $)$ and the oil treated with the $2000 \mathrm{ppm}$ level of FIPE after 21 days of storage, which indicated excellent antioxidant capacity at higher concentration levels of FIPE.
The variation in the PV of sunflower oil treated with FIPE is illustrated in Figure 2. The PVs of all the tested oil samples were increased with time, which indicated the generation of hydroperoxides in sunflower oil (Szydłowska-Czerniak and Rabiej, 2018). The PVs of sunflower oil samples were higher than that of VCO owing to the high amount of unsaturated fatty acids present in SO which are more prone to oxidation (Wójcickiwt et al., 2015). The PV of oil samples treated with the $2000 \mathrm{ppm}$ level of FIPE after 21 days of storage was 12.38 $\pm 0.46 \mathrm{meq} / \mathrm{kg}$; while the control and $\alpha$-tocopherol showed $28.30 \pm 0.58$ meq $\mathrm{O}_{2} \cdot \mathrm{kg}^{-1}$ and $17.94 \pm 0.35$ meq $\mathrm{O}_{2} \cdot \mathrm{kg}^{-1}$, respectively. However, there was no significant difference between the control and treatments until day 6. From day 9 onwards the PV of SO treated with the $2000 \mathrm{ppm}$ level of FIPE was significantly $(p<0.05)$ lower than that of the positive control, $\alpha$-tocopherol. Moreover, there was no significant difference between $\mathrm{SO}$ with $500 \mathrm{ppm}$ or $1000 \mathrm{ppm}$ level of FIPE addition. However, the $\mathrm{PV}$ of the positive control was significantly lower than those of $500 \mathrm{ppm}$ and $1000 \mathrm{ppm}$ levels of 

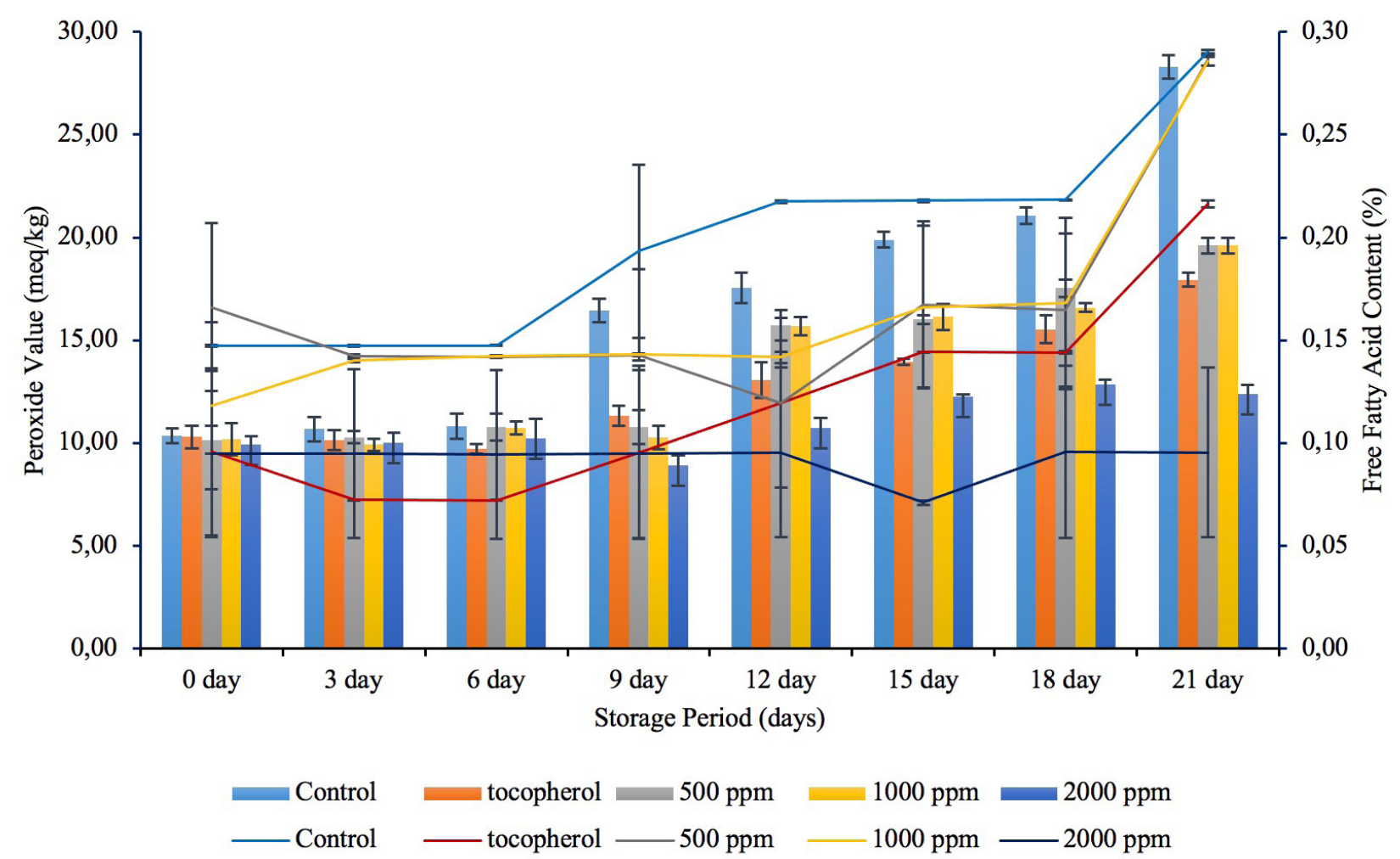

FIgure 2. Variations in Peroxide Value and Free Fatty Acid Content in Sunflower oil with added FIPE. Values are presented as mean \pm SD of three determinations.

FIPE-added SO samples, thus proving the efficacy of $2000 \mathrm{ppm}$ level of FIPE addition in controlling the oxidation of SO.

\subsection{Variation of free fatty acid (FFA) content during storage of oils}

Free fatty acid content is one of the important quality parameters in oils, as FFA is responsible for the development of undesirable flavor and aroma in oils. These free fatty acids formed in oils from hydrolysis, oxidation due to free radical formation and cleavage of double bonds during frying (Ma et al., 2015). The free fatty acid content of VCO used for the study was relatively low $(0.26 \pm 0.04 \%)$ indicating that the initial quality of VCO used for the study was good. However, the FFA content in the present study was higher than that of the reported study $(0.16 \pm 0.002 \%)$ (Rohman et al., 2011). The variation in FFA contents in the VCO samples treated with FIPE are shown in Figure 1 along with the control and positive control, $\alpha$-tocopherol. The FFA content in VCO treated with FIPE at the 2000 ppm level was significantly $(\mathrm{p}<0.05)$ lower than that of the control after day 3. However, there was no significant difference between the FFA content of the $2000 \mathrm{ppm}$ level of extract-added oil and the positive control after 3 days of storage. Initially, FFA content was not significantly different from the control and treated oil samples. However, with time the FFA contents in the oil samples were increased as shown in Figure 1. After 21 days of storage the VCO (control) sample exhibited the highest FFA content $(0.36 \pm 0.00 \%)$; while the $2000 \mathrm{ppm}$ level of extract-added oil sample contained the lowest FFA content $(0.28 \pm 0.00 \%)$. In addition, after 21 days of storage the FFA content of $2000 \mathrm{ppm}$ level of extract-added sample was significantly lower than that of the positive control $(0.29 \pm 0.00 \%)$.

The initial FFA content of SO $(0.15 \pm 0.00 \%)$ used for the study was lower than that of VCO $(0.26$ $\pm 0.04 \%$ ). A comparatively high initial FFA content of VCO could be attributed to the presence of free fatty acids, chlorophyll or products of oxidative degradation which impair the quality of the oil (Ma et al., 2015). Many studies were conducted to assess the effect of the addition of natural antioxidants on 
the oxidative stability of SO (Carelli et al., 2005). The initial FFA content in the reported study $(0.16 \%)$ was comparable to the present study. The FFA content of SO treated with the $2000 \mathrm{ppm}$ level of extract was significantly $(p<0.05)$ lower than that of the control from day 3 onwards. However, there was no significant difference between oil treated with $2000 \mathrm{ppm}$ level of extract and $\alpha$-tocopherol until 21 days of storage. After 21 days of storage SO treated with the $2000 \mathrm{ppm}$ level of FIPE exhibited the lowest FFA content $(0.10 \pm 0.04 \%)$; while oil treated with $500 \mathrm{ppm}$ and $1000 \mathrm{ppm}$ levels of extracts showed comparatively high FFA content (Figure 2). Moreover, there was no significant difference between the control and SO treated with $500 \mathrm{ppm}$ and 1000 ppm extract levels after 21 days of storage.

\subsection{FTIR analysis of stored edible oils}

The influx of research studies was carried out on the potential applications of FTIR in monitoring the oxidation of edible oils (Van de et al., 1994). Thus, the present study used FTIR spectroscopy to monitor the oxidative changes occurring in treated and non-treated sunflower oil and virgin coconut oil after 21 days of storage. Figure 3 illustrates the FTIR spectra of non-treated VCO, VCO treated with the 2000 ppm level of FIPE and VCO treated with $\alpha$-tocopherol. Among other edible oils VCO has a unique spectrum, as shown in Figure 3. In the spectra of VCO no peaks are identified at the region of $3008 \mathrm{~cm}^{-1}$ and $1655 \mathrm{~cm}^{-1}$ which is in agreement with previous studies (Rohman and CheMan, 2011). Peaks in the above-mentioned region represent the unsaturated double bonds and are used to express the degree of unsaturation of triglycerides. Since VCO contains very low levels of unsaturated fatty acids, the peak is hardly noticeable in this region (Rohman and CheMan, 2011).

Peaks appearing at $721,962,1744,2852$, 2927 and $3300 \mathrm{~cm}^{-1}$ were selected to compare the differences between the treated and non-treated VCO samples used for the study. All the VCO samples failed to show a peak at around $3444 \mathrm{~cm}^{-1}$ (Figure 03), hence no evidence was detected for the

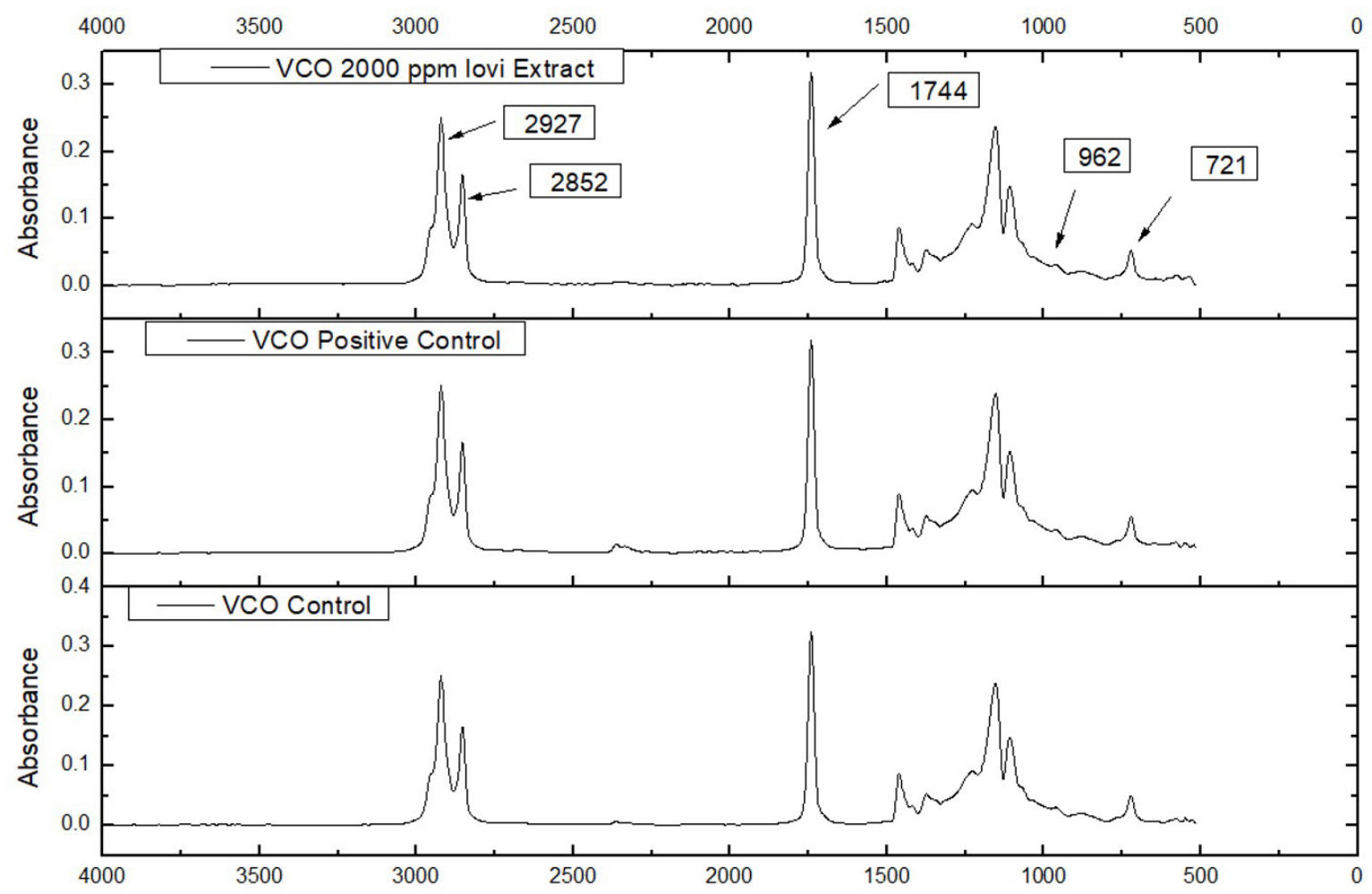

Wavenumber $2927,2852,1744,962,721$ corresponding respectively to the $-\mathrm{C}-\mathrm{H}\left(\mathrm{CH}_{3}\right)$ stretching, $-\mathrm{C}-\mathrm{H}\left(\mathrm{CH}_{2}\right)$ stretching, $-\mathrm{C}=\mathrm{O}(\mathrm{ester})$ stretching, trans- $\mathrm{CH}=\mathrm{CH}-$ bending and cis $-\mathrm{CH}=\mathrm{CH}-$ bending according to Rohman and CheMan, 2011.

FIGURE 3. FTIR spectrum of treated and non-treated virgin coconut oils (VCO) after 21 days of storage 
$8 \cdot$ N.E. Wedamulla and W.A.J.P. Wijesinghe
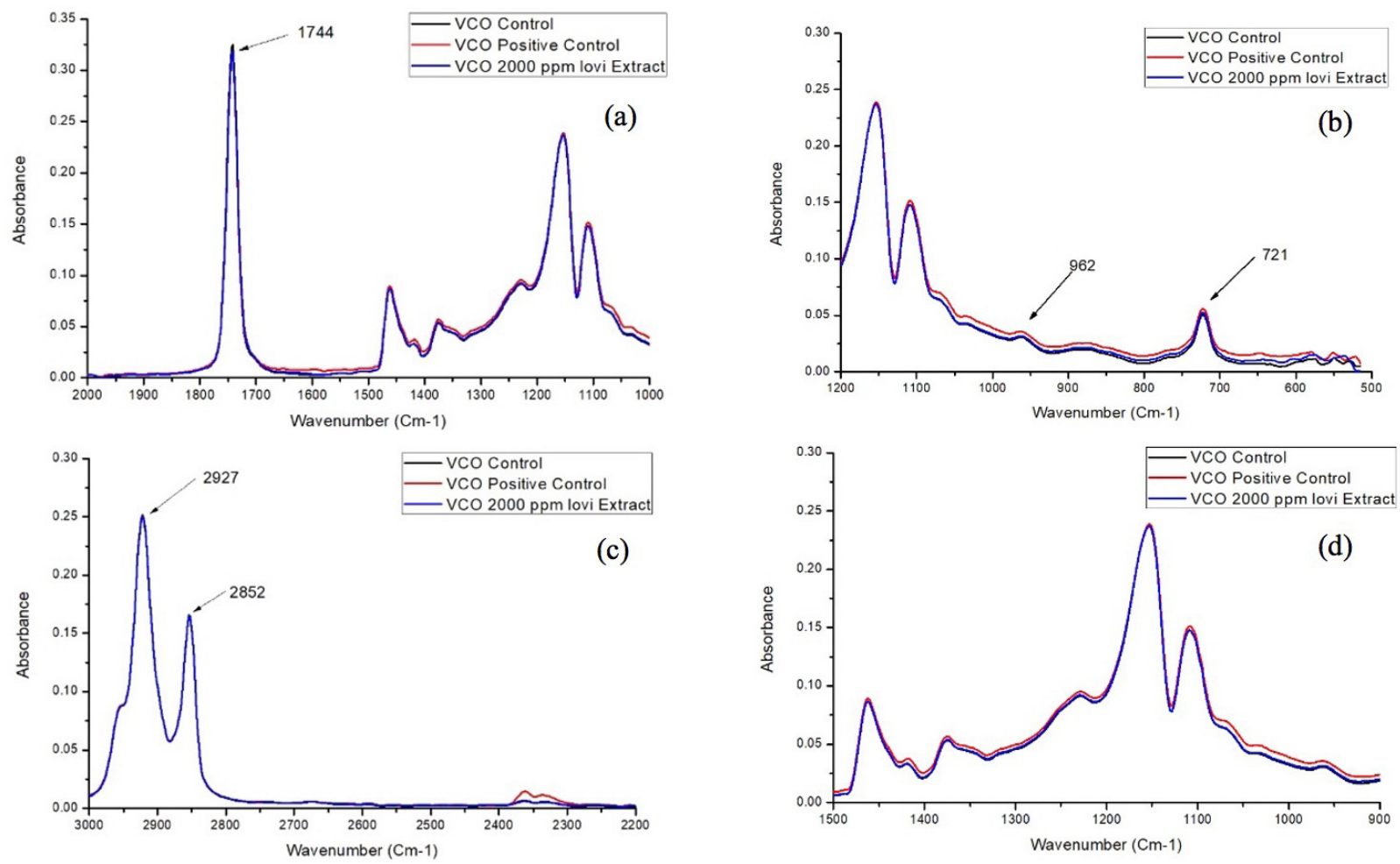

Wavenumber $2927,2852,1744,962,721$ corresponding respectively to the $-\mathrm{C}-\mathrm{H}\left(\mathrm{CH}_{3}\right)$ stretching, $-\mathrm{C}-\mathrm{H}\left(\mathrm{CH}_{2}\right)$ stretching, $-\mathrm{C}=\mathrm{O}(\mathrm{ester})$ stretching, trans $-\mathrm{CH}=\mathrm{CH}-$ bending and cis $-\mathrm{CH}=\mathrm{CH}-$ bending according to Rohman and CheMan, 2011.

FIGURE 4. Magnification of FTIR spectra of virgin coconut oil (VCO) a) at region 2000 to $1000 \mathrm{~cm}^{-1} \mathrm{~b}$ ) at region 1200 to $500 \mathrm{~cm}^{-1}$ c) at region 3000 to $2200 \mathrm{~cm}^{-1} \mathrm{~d}$ ) at region 1500 to $900 \mathrm{~cm}^{-1}$

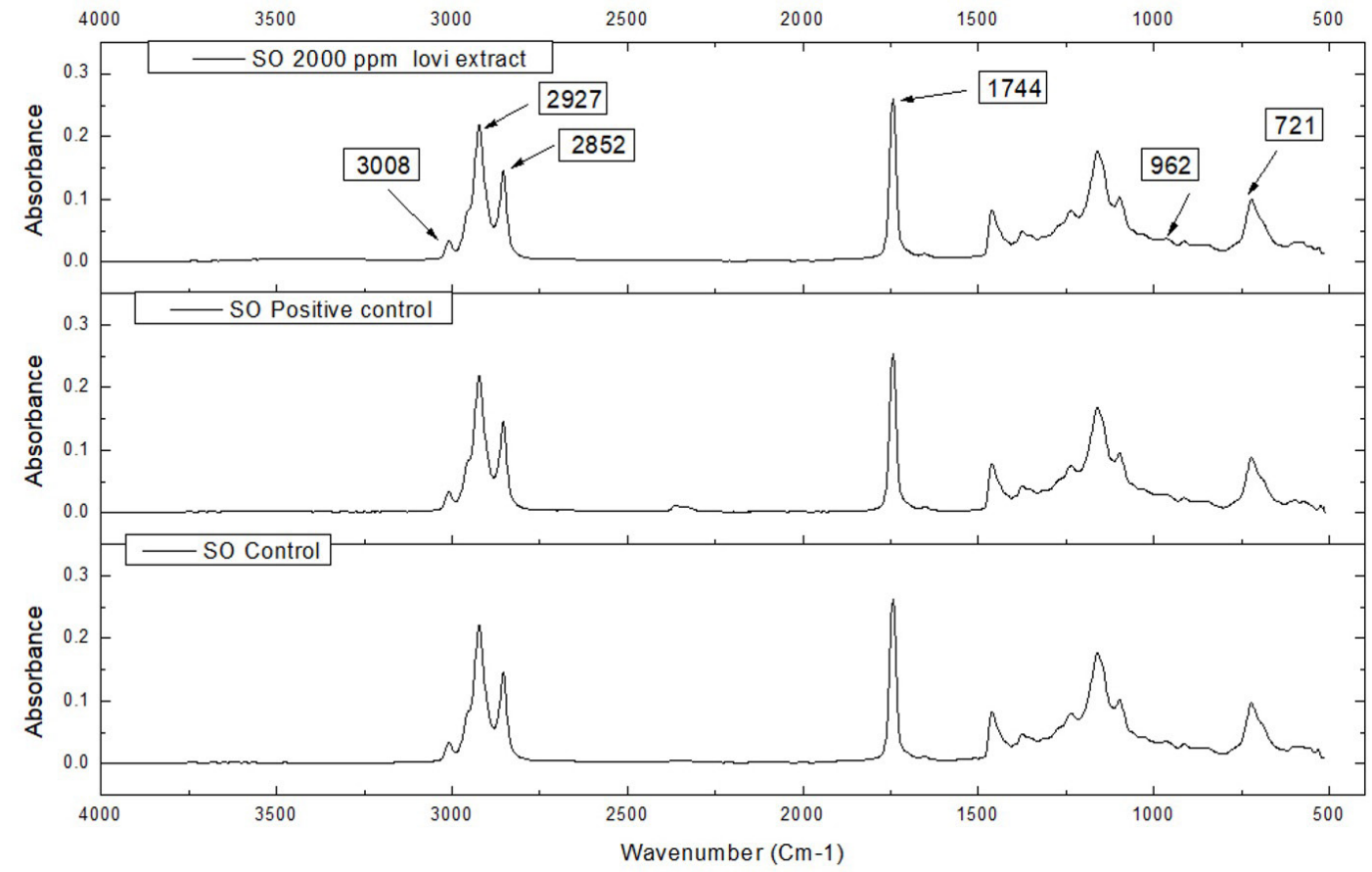

Wavenumber 3008, 2927, 2852, 1744, 962,721 corresponding respectively to the $=\mathrm{C}-\mathrm{H}$ (cis) stretching, $-\mathrm{C}-\mathrm{H}\left(\mathrm{CH}_{3}\right)$ stretching, $-\mathrm{C}-\mathrm{H}$ $\left(\mathrm{CH}_{2}\right)$ stretching, $-\mathrm{C}=\mathrm{O}$ (ester) stretching, trans- $\mathrm{CH}=\mathrm{CH}-$ bending and cis- $\mathrm{CH}=\mathrm{CH}-$ bending according to Rohman and CheMan, 2011.

FIGURE 5. FTIR spectra of treated and non-treated sunflower oil (SO) after 21 days of storage 

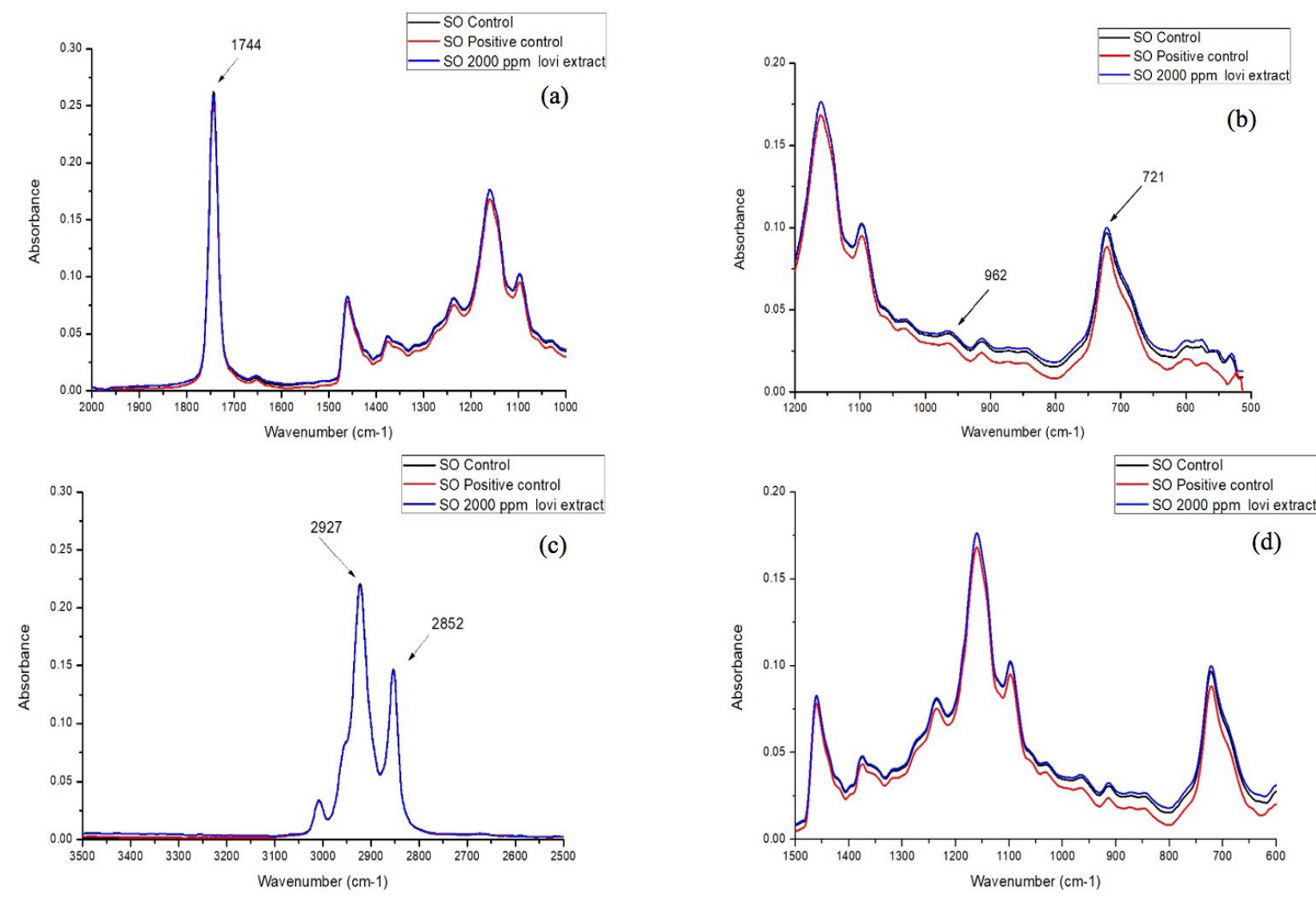

Wavenumber 2927, 2852, 1744, 962,721 corresponding respectively to the $-\mathrm{C}-\mathrm{H}(\mathrm{CH} 3)$ stretching, $-\mathrm{C}-\mathrm{H}(\mathrm{CH} 2)$ stretching, $-\mathrm{C}=\mathrm{O}$ (ester) stretching, trans- $\mathrm{CH}=\mathrm{CH}-$ bending and cis- $\mathrm{CH}=\mathrm{CH}-$ bending according to Rohman and CheMan, 2011.

FIGURE 6. Magnification of FTIR spectra of sunflower oil (SO) a) at region 2000 to $1000 \mathrm{~cm}^{-1} \mathrm{~b}$ ) at region 1200 to $500 \mathrm{~cm}^{-1}$ c) at region 3500 to $2500 \mathrm{~cm}^{-1} \mathrm{~d}$ ) at region 1500 to $900 \mathrm{~cm}^{-1}$

presence of hydroperoxides or free fatty acids which are formed in the thermal oxidation of oils. The carbonyl absorption of the triacylglyceol linkage is noticeable at $1744 \mathrm{~cm}^{-1}$. However, a noticeable difference was not observed in VCO samples at this frequency (Figure 4 (a)). High intensity at $1744 \mathrm{~cm}^{-1}$ represents the high amounts of carbonyl compounds such as aldehydes, esters, ketones, and lactones present in the oils which formed during oxidation (Smith et al., 2005). Moreover, added FIPE and $\alpha$-tocopherol were not effective in lowering the intensity of carbonyl compounds (Figure 4 (a)). The peak at $962 \mathrm{~cm}^{-1}$ represents the bending vibration of $\mathrm{CH}$ functional groups of trans olefins. This peak serves as indicator of oxidative stability as the peak provides the information relevant to gradual cis to trans isomerization in the oxidized oil (Marina et al., 2013). There was a minor difference in the peak intensities of $\mathrm{VCO}$ at $962 \mathrm{~cm}^{-1}$; the highest peak intensity represented the VCO treated with $\alpha$ - tocopherol followed by the VCO treated with the 2000 ppm level of FIPE and VCO without any treatment (Figure 4 (b)). The peak revealed in the $721 \mathrm{~cm}^{-1}$ region also displayed similar variation as the intensity variation in peak appeared in the 962 $\mathrm{cm}^{-1}$ region; the VCO sample stored for 21 days without any treatment exhibited the lowest intensity. The peaks appeared in the $2927 \mathrm{~cm}^{-1}$ and $2852 \mathrm{~cm}^{-1}$ regions also exhibited minor differences (Figure 4 (c)). One of the important regions of the FTIR spectra for VCO is the region of 1500 to $1000 \mathrm{~cm}^{-1}$, which is also known as the finger print region (Marina et al., 2013). There is no noticeable difference revealed in the spectra of treated and non-treated VCO in this region (Figure 4 (d)).

Figure 5 illustrates the FTIR spectra of non-treated SO, SO treated with the $2000 \mathrm{ppm}$ level of lovi peel extract and SO treated with $\alpha$-tocopherol. In the 
FTIR spectra of SO no peak is revealed at $3444 \mathrm{~cm}^{-1}$, which represent the hydroperoxide functional group. With the progression of oxidation hydroperoxide formation increases and in relation to that, the intensity of the band revealed at $3444 \mathrm{~cm}^{-1}$ also increases gradually (Hamed and Allam, 2006). However, the spectra of SO revealed a peak at $3008 \mathrm{~cm}^{-1}$, which represents the unsaturated double bond (Rohman and Man, 2011). Since SO contains comparatively high levels of unsaturated fatty acids the peak appeared in this region, but that peak is not revealed in the spectra of VCO.

Figure 6 illustrates the magnification of spectral ranges $2000-1000 \mathrm{~cm}^{-1}, 1200-500 \mathrm{~cm}^{-1}, 3500-2500 \mathrm{~cm}^{-1}$ and $1500-900 \mathrm{~cm}^{-1}$ in the FTIR spectra of treated and non-treated SO samples. Similar to the VCO a significant difference was not observed between the treated and non-treated SO samples at $1744 \mathrm{~cm}^{-1}$ (Figure 6 (a)). In non-oxidized oil this peak solely represents the ester carbonyl functional group of triglycerides and when the oil is oxidized, this peak overlaps with aldehydes, thereby producing a decrease in intensity (Guillén and Goicoechea, 2007). Figure 6(b) illustrates the differences in peak intensities between treated and non-treated SO samples at $962 \mathrm{~cm}^{-1}$. The positive control, $\alpha$-tocopherol, exhibits the lowest peak intensity. While the FIPE-added sample shows the highest peak intensity. This peak represents the gradual cis to trans isomerization in the oxidized oil, which increases with the progression of oxidation (Marina et al., 2013). Thus, $\alpha$-tocopherol is effective in controlling the oxidation of SO since it exhibits the lowest peak intensity. The peak at $722 \mathrm{~cm}^{-1}$ was decreased with the progression of oxidation due to the loss of cis double bonds (Rohman and Che Man, 2013). The Figure 6(b) illustrates the differences in peak intensities at $722 \mathrm{~cm}^{-1}$. As illustrated in the figure, the SO sample treated with FIPE extract exhibits the highest peak intensity and thereby represents the lowest rate of oxidation. Two peaks at 2853 and $2923 \mathrm{~cm}^{-1}$ remained unchanged. However, minor differences were observed in the peak intensities of treated and non-treated SO samples in the finger print region of the FTIR spectra (Figure 6(d)).

\section{CONCLUSIONS}

The present study concluded that the extract from the peel of lovi (Flacourtia inermis) has strong antioxidant activity with high total phenol content. Moreover, FIPE shows excellent protective effects against the oxidation of virgin coconut oil and sunflower at the $2000 \mathrm{ppm}$ concentration level. The findings in the storage study have confirmed that the FIPE under the study conditions could be used as an alternative to $\alpha$-tocopherol in order to improve the oxidative stability of virgin coconut oil and sunflower oil. However, only the minor differences were revealed in the FTIR spectra of treated and non-treated virgin coconut oil and sunflower oil samples after 21 days of storage at $65 \pm 5{ }^{\circ} \mathrm{C}$.

\section{ACKNOWLEDGMENTS}

This work was supported by the University Research Grant (UWU/RG/2018/004); Uva Wellasaa University, Badulla, Sri Lanka.

\section{REFERENCES}

Abdelazim AA, Mahmoud A, Ramadan-Hassanien MF. 2013. Oxidative stability of vegetable oils as affected by sesame extracts during accelerated oxidative storage. J. Food Sci. Technol. 50, 868878. https://doi.org/10.1007/s13197-011-0419-8

Alakolanga AGAW, Siriwardane AMDA, Kumar NS, Jayasinghe L, Jaiswal R, Kuhnert N. 2014. LC-MS ${ }^{\mathrm{n}}$ identification and characterization of the phenolic compounds from the fruits of Flacourtia indica (Burm. F.) Merr. and Flacourtia inermis Roxb. Food Res. Int. 62, 388-396. https://doi. org/10.1016/j.foodres.2014.03.036

Alakolanga AG, Kumar NS, Jayasinghe L, Fujimoto Y. 2015. Antioxidant property and $\alpha$-glucosidase, $\alpha$-amylase and lipase inhibiting activities of Flacourtia inermis fruits: characterization of malic acid as an inhibitor of the enzymes. J. Food Sci. Technol. 52, 8383. https://doi.org/10.1007/ s13197-015-1937-6

Ali AMA, El-Nour MEM, Yagi SM. 2018. Total phenolic and flavonoid contents and antioxidant activity of ginger (Zingiber officinale Rosc.) rhizome, callus and callus treated with some elicitors. J. Genet. Eng. Biotechnol. 16, 677-682. https://doi.org/10.1016/j.jgeb.2018.03.003

Annegowda HV, Anwar LN, Mordi MN, Ramanathan S, Mansor SM. 2010. Influence of sonication on the phenolic content and antioxidant activity of Terminalia catappa L. leaves. Pharmacognosy. Res. 2, 368-373. https://doi.org/10.4103/09748490.75457 
AOAC 940.28. 2016. Fatty acids (Free) in crude oil and refined oils. In: Official methods of analysis of AOAC International, 20 th ed. Maryland: AOAC International.

AOAC 965.33. 2016. Peroxide value in oils and fats. In: Official methods of analysis of AOAC International, 20 th ed. Maryland: AOAC International.

Arshad MU, Amjad MU. 2012. Medicinal use of sunflower oil and present status of sunflower in Pakistan: A Review Study. Sci. Tech. Dev. 31, 99-106.

Besbes S, Blecker C, Deroanne C, Lognay G, Drira NE, Attia H. 2004. Quality characteristics and oxidative stability of date seed oil during storage. Food Sci. Technol. Int. 10, 333-338. https://doi. org/10.1177/1082013204047777

Capuano E, Oliviero T, Açar ÖÇ, Gökmen V, Fogliano V. 2010. Lipid oxidation promotes acrylamide formation in fat-rich model systems. Food Res. Int. 43, 1021-1026. https://doi.org/10.1016/j. foodres.2010.01.013

Carelli AA, Franco IC, Crapiste GH. 2005. Effectiveness of added natural antioxidants in sunflower oil. Grasas Aceites 56, 303-310. https://doi. org/10.3989/gya.2005.v56.i4.97

Choe E, Min DB. 2006. Mechanisms and Factors for Edible Oil Oxidation. Compr. Rev. Food Sci. Food Saf. 5, 69-186. https://doi.org/10.1111/ j.1541-4337.2006.00009.x

Falowo AB, Fayemi PO, Muchenje V. 2014. Natural antioxidants against lipid-protein oxidative deterioration in meat and meat products: A review. Food Res. Int. 64, 171-181. https://doi. org/10.1016/j.foodres.2014.06.022

Guillén MD, Cabo N. 2002. Fourier transform infrared spectra data versus peroxide and anisidine values to determine oxidative stability of edible oils. Food Chem. 77, 503-510. https://doi. org/10.1021/jf071712c

Guillén MD, Goicoechea E. 2007. Detection of primary and secondary oxidation products by Fourier transform infrared spectroscopy (FTIR) and ${ }^{1} \mathrm{H}$ nuclear magnetic resonance (NMR) in sunflower oil during storage. J. Agric. Food Chem. 55, 10729-10736. https://doi.org/10729-10736. 10.1021/jf071712c

Hamed SF, Allam MA. 2006. Application of FTIR spectroscopy in the determination of antioxidant efficiency in sunflower oil. J. of Appl. Sc. Res. 2 , 27-33.
ISO 14502-1. 2005. Determination of substances characteristic of green and black tea - Part 1: Content of total polyphenols in tea - Colorimetric method using Folin-Ciocalteu reagent. Geneva: ISO.

Jayasinghe L, Lakdusinghe M, Hara N, Fujimoto Y. 2012. Phenolic constituents from the fruit juice of Flacourtia inermis. Nat. Prod. Res. 26, 278-281. https://doi.org/10.1080/14786419.2011.586638

Latha RB. 2009. Storage stability of sunflower oil with added natural antioxidant concentrate from sesame seed oil. J. Oleo Sci. 58, 453-459.

Lercker G, Rodriguez-Estrada MT. 2002. Cholesterol oxidation mechanism, in Guardiola F, Dutta PC, Codony R, Savage GP. (Eds.). Cholesterol and phytosterol oxidation products: Analysis, occurrence and biological effects, Champaign, IL: AOCS Press, pp. 1-26.

Liew SS, Ho WY, Yeap SK, Sharifudin SAB. 2018. Phytochemical composition and in vitro antioxidant activities of Citrus sinensis peel extracts. Peer J. 6, e5331. https://doi.org/10.7717/ peerj.5331. eCollection 2018

Ma JK, Zhang H, Tsuchiya T, Akiyama Y, Chen JY. 2015. Frying stability of rapeseed Kizakinonatane (Brassica napus) oil in comparison with canola oil. Food Sci. Technol. Int. 21, 163-174. https://doi.org/10.1177/1082013213520173

Madhavi BR, Devi NKD, Mrudula BS, Babu RN. 2010. The importance of biodegradable bio-oil-Sunflower. Int. J. Pharm. Tech. Res. 2, 1913-1915.

Marina AM, Rosli WI, Noorhidayah M. 2013. Quantitative analysis of peroxide value in virgin coconut oil by ATRFTIR spectroscopy. Open Conf. Proc. J. 4, 53-56. https://doi. org/10.2174/2210289201304020053

Naczk M, Shahidi F. 2004. Extraction and analysis of phenolics in food. J. Chromatogr. A. 1054, 95-111. https://doi.org/10.1016/S00219673(04)01409-8

Piyathunga ALI, Mallawaarachchi MALN, Madhujith WMT. 2016. Phenolic Content and Antioxidant Capacity of Selected Underutilized Fruits Grown in Sri Lanka. Tropl. Agricl. Res. 27, $277-$ 286. http://doi.org/10.4038/tar.v27i3.8206

Rohman A, Che Man YB. 2011. Potential use of FTIR-ATR spectroscopic method for determination of virgin coconut oil and extra virgin olive oil in ternary mixture systems. Food Anal. Methods 4, 155162. https://doi.org/10.1007/s12161-010-9156-2 
Rohman A, Che Man YB. 2013. Application of FTIR spectroscopy for monitoring the stabilities of selected vegetable oils during thermal oxidation. Int. J. Food Pro. 16, 1594-1603. https://doi.org/1 0.1080/10942912.2011.603874

Rohman A, Che Man YB, Ismail A, Hashim P. 2011. Monitoring the oxidative stability of virgin coconut oil during oven test using chemical indexes and FTIR spectroscopy. Int. Food Res. $J$. 18, 303-310.

Smith SA, King RE, Min DB. 2005. Oxidative and thermal stabilities of genetically modified high oleic sunflower oil. Food Chem. 102, 1208-1213. https://doi.org/10.1016/j.foodchem.2006.06.058

Szydłowska-Czerniak A, Rabiej D. 2018. Octylsinapate as a new antioxidant to improve oxidative stability and antioxidant activity of rapeseed oil during accelerated storage. Eur. Food Res. Technol. 244, 1397-1406.

Van de Voort FR, Ismail AA, Sedman J, Emo G. 1994. Monitoring the oxidation of edible oils by Fourier transform infrared spectroscopy. $J$. Am. Oil Chem. Soc. 71, 243-253. https://doi. org/10.1007/BF02638049

Villarino BJ, Dy LM, Lizada M. 2007. Descriptive sensory evaluation of virgin coconut oil and refined, bleached and deodorized coconut oil. $L W T$ - Food Sci. Technol. 40, 193-199. https://doi. org/10.1016/j.lwt.2005.11.007

Wójcicki K, Khmelinskii I, Sikorski M, Sikorska E. 2015. Near and mid infrared spectroscopy and multivariate data analysis in studies of oxidation of edible oils. Food Chem. 187, 416-423. https:// doi.org/10.1016/j.foodchem.2015.04.046 